\title{
PENINGKATAN KOMPETENSI ASESOR MELALUI KEGIATAN PEMBEKALAN ASESOR AKREDITASI TAHAP KPA DI BAN PAUD DAN PNF PROVINSI SULAWESI TENGAH
}

\author{
Riady Ibnu Khaldun'1) \\ ${ }^{1)}$ Fakultas IImu Sosial dan IImu Politik, Universitas Sulawesi Barat, Majene, Sulawesi Barat, Indonesia \\ Corresponding author : Riady Ibnu Khaldun \\ E-mail : riadyibnu@unsulbar.ac.id
}

Diterima 10 Juli 2021, Direvisi 10 Agustus 2021, Disetujui 10 Agustus 2021

\begin{abstract}
ABSTRAK
Pembekalan asesor akreditasi yang diselenggarakan oleh BAN PAUD dan PNF di Tahun 2021 merupakan kegiatan yang harus diikuti oleh setiap asesor baik rumpun PAUD maupun PKBM sebagai syarat agar dapat ditugaskan dalam kegiatan akreditasi seperti penilaian Klasifikasi Permohonan Akreditasi (KPA), Visitasi, serta Validasi dan Verivikasi. Narasumber pada kegiatan ini adalah asesor yang telah mengikuti dan dinyatakan lulus pada kegiatan Pelatihan Calon Pelatih (PCP) Asesor BAN PAUD dan PNF. Proses pelaksanaan kegiatan pembekalan asesor akreditasi dilakukan secara online dengan menggunakan aplikasi Zoom Meeting. Pengabdi berkontribusi kepada mitra yakni BAN PAUD dan PNF Provinsi Sulawesi Tengah sebagai narasumber untuk memberikan pembekalan kepada asesor berupa pemaparan materi dan mendampingi para peserta ketika melakukan praktik pelaksanaan akreditasi KPA. Hasil dari kegiatan tersebut adalah para peserta dapat melakukan penilaian KPA yakni verivikasi dan pengecekan kesesuaian dokumen yang diajukan oleh satuan PAUD dengan yang dipersyaratkan berdasarkan panduan pelaksanaan akreditasi Tahun 2021.
\end{abstract}

Kata kunci: peningkatan kompetensi; pembekalan asesor akreditasi; klasifikasi permohonan akreditasi

\begin{abstract}
Improving the competence of assessors is important in order to deal with all stages of the accreditation process. The provision of accreditation assessors activities held by BAN PAUD and PNF in 2021 is a provision that must be followed by assessors, both PAUD and PKBM clusters in order to be assigned to accreditation activities, both accreditation assessment, visits, as well as validation and verification supported by the development of instruments that produce assessment instruments. accreditation. The process of implementing the debriefing activity for accreditation assessors is carried out online using the Zoom Meeting application. The form of contribution given to BAN PAUD and PNF Province of Central Sulawesi as a presenter to provide briefing to assessors in the form of presentation of material on data tracing techniques at the KPA stage, the PPA instrument, and assisting participants when carrying out the practice of implementing KPA. The result of this activity is that participants can carry out KPA assessments, namely verification and checking of the suitability of documents submitted by PAUD units with those required based on the 2021 accreditation implementation guidelines.
\end{abstract}

Keywords: competency improvement; accreditation assessor debriefing; classification of accreditation applications

\section{PENDAHULUAN}

Memasuki era globalisasi saat ini, menyebabkan dunia telah memasuki kondisi tanpa batas (borderless) yakni setiap individu dapat berinteraksi dengan mudah di manapun dan kapanpun karena didukung dengan perkembangan teknologi baik transportasi maupun komunikasi yang sangat mutakhir (Fikri, 2019). Demikian halnya, tantangan terbesar yang harus dihadapi dengan situasi sekarang adalah penyebaran virus penyebab penyakit sangat masif karena akses perpindahan manusia dari satu tempat ke tempat lainnya di seluruh dunia tidak dapat lagi terbendung menyebabkan satu di antaranya yaitu Corona Virus Disease (Covid-19) menjadi pandemi global di Tahun 2020 (Handayani et al., 2020). Pandemi tersebut merubah tatanan hidup global menjadi tatanan hidup kenormalan baru (new normal), di Indonesia seperti yang terjadi di sektor pendidikan di mana beberapa sekolah baik di tingkat Pendidikan Anak Usia Dini (PAUD), Sekolah Dasar (SD), Sekolah Menengah Pertama 
(SMP), Sekolah Menengah Atas (SMA), maupun universitas melaksanaan sistem pembelajaran secara daring dikenal dengan nama pembelajaran jarak jauh (Sari et al., 2020). Didukung dengan beberapa aturan mengenai pencegahan dan penanganan penyebaran Covid-19, maka beberapa kegiatan harus berjalan secara online termasuk kegiatan yang dilakukan oleh BAN PAUD dan PNF seperti pelaksanaan akreditasi pada Tahun 2021.

Dalam rangka menyukseskan kegiatan akreditasi di Tahun 2021 maka BAN PAUD dan PNF melaksanakan kegiatan untuk meningkatkan kompetensi para asesor sebelum mengikuti seluruh tahapan kegiatan akreditasi baik Klasifikasi Permohonan Akreditasi (KPA), Visitasi, maupun Validasi dan Verivikasi yakni dalam bentuk kegiatan pembekalan akreditasi. Kegiatan pembekalan tersebut juga diperlukan berdasarkan pertimbangan pada Tahun 2020, BAN PAUD dan PNF telah melakukan pengembangan dan penyempurnaan instrumen dari instrumen yang sebelumnya serta mengembangkan sistem penilaian akreditasi terbaru yaitu Sispena 3.1.

Pengembangan dan penyempurnaan baik instrumeni maupun sistem penilaian akreditasi tersebut harus dipahami dan dapat diaplikasikan oleh setiap asesor, sehingga para asesor perlu untuk mendapatkan pembekalan sebelum mengikuti seluruh tahapan akreditasi. Adapun kegiatan pertama pembekalan asesor akreditasi adalah pada tahap KPA di mana para asesor perlu memahami bagaimana kebijakan dan mekanisme akreditasi PAUD dan PNF pada pelaksanaan KPA, teknik penulusuran data pada tahapan KPA, instrumen Penilaian Prasyarat Akreditasi (PPA), serta praktik pelaksanaan akreditasi pada tahap KPA.

Pada tahap penilaian KPA, tugas para asesor adalah melakukan verivikasi dokumen satuan PAUD yang telah mengisi instrumen PPA sesuai dengan manual menggunakan aplikasi Sispena 3.1. Permasalahan mitra adalah perlunya dilakukan pembekalan asesor akreditasi tahap KPA, agar para asesor dapat melakukan verivikasi dan pengecekan kesesuaian dokumen yang diajukan oleh satuan PAUD dengan yang dipersyaratkan. Diharapkan dengan terlaksananya kegiatan ini, pengabdi dapat memberikan kontribusi kepada mitra sebagai narasumber untuk memberikan pembekalan kepada asesor sehingga dapat melaksanakan penilaian KPA sesuai dengan panduan pelaksanaan akreditasi Tahun 2021.

\section{METODE}

Kegiatan pembekalan asesor akreditasi tahap KPA diselenggarakan oleh BAN PAUD dan PNF Provinsi Sulawesi Tengah untuk meningkatkan kompetensi asesor sebelum melaksanakan penilaian KPA. Adapun peserta yang mengikuti kegiatan ini adalah para asesor baik dari rumpun PAUD maupun PKBM yang berasal dari Provinsi Sulawesi Tengah dengan jumlah 43 orang. Kegiatan ini dilaksanakan secara daring dengan menggunakan aplikasi Zoom Meeting (Farfar, 2021). Pelaksanaan kegiatan ini dibagi ke dalam empat tahap yaitu: 1) pembukaan oleh Ketua BAN PAUD dan PNF Provinsi Sulawesi Tengah; 2) penjelasan teknis oleh Panitia BAN PAUD dan PNF Provinsi Sulawesi Tengah; 3) paparan oleh narasumber dilanjutkan dengan tanya jawab; dan 4) kegiatan praktik serta diskusi bersama para peserta.

Adapun metode yang digunakan dalam pengabdian kepada masyarakat ini adalah (Junining et al, 2021): 1) ceramah bervariasi yaitu cara penyampaian dan penyajian materi menggunakan berbagai metode seperti tanya jawab, diskusi terbatas, dan sebagainya (Herawati et al., 2020). Ceramah bervariasi sangat berguna digunakan dalam menyampaikan materi kegiatan. Penggunaan metode ceramah bervariasi juga didasari dengan tingginya tingkat keberhasilan penyeparan materi oleh para peserta apabila materi disajikan dengan tampilan yang menarik; 2) demonstrasi yaitu metode yang digunakan berupa pemberian contoh langsung kepada para peserta tentang penilaian KPA; 3 ) latihan yaitu para peserta melakukan praktik penilaian KPA; dan 4) diskusi yaitu memberikan kesempatan kepada para peserta untuk memaparkan hasil penilaian KPAnya dan melakukan diskusi secara bersama.

\section{HASIL DAN PEMBAHASAN}

Pembekalan asesor akreditasi pada Tahun 2021 merupakan kegiatan yang diselenggarakan oleh BAN PAUD dan PNF dengan tujuan untuk meningkatkan kompetensi asesor dalam melaksanakan kegiatan akreditasi pada setiap tahapan yaitu KPA, Visitasi, serta Validasi dan Verivikasi. Banyaknya jumlah asesor baik rumpun PAUD dan PKBM di Indonesia, maka pelaksanaan kegiatan tersebut dilakukan di setiap BAN PAUD dan PNF Provinsi termasuk BAN PAUD dan PNF Provinsi Sulawesi Tengah.

Dasar penyelenggaraan kegiatan tersebut disebabkan oleh adanya penyempurnaan instrumen akreditasi di Tahun 2020 dan sistem penilaian akreditasi, sehingga setiap asesor BAN PAUD dan PNF diharapkan dapat memahami dan mengaplikasikan baik instrumen maupun sistem yang telah 
disempurnakan tersebut. Kegiatan pengabdian kepada masyarakat ini terlaksana dalam bentuk pembekalan asesor akreditasi tahap KPA di mana para asesor dibekali materi dan praktik untuk dapat melakukan penilaian kesesuaian dokumen yang diunggah oleh setiap satuan PAUD pada saat melakukan pengisian instrumen penilaian prasyarat akreditasi.

Pengabdi dapat berkontribusi kepada mitra sebagai narasumber karena telah mengikut kegiatan Pelatihan Calon Pelatih (PCP) Asesor BAN PAUD dan PNF Tahun 2021. Pelaksanaan kegiatan ini mendapatkan respon yang positif dari para peserta didukung dengan jumlah keikutsertaan peserta kegiatan yang hadir yaitu sebanyak 42 orang dari total 43 yang diusulkan. Kegiatan ini diawali dengan pra-pelaksanaan yaitu beberapa hari sebelum kegiatan dimulai, para peserta telah mengisi instrumen penilaian prasyarat akreditasi pada satuan PAUD yang diajukan melalui tautan Sispena simulasi menggunakan NPSN. Selanjutnya, beberapa tahapan yang telah terlaksana di dalam kegiatan ini dijabarkan sebagai berikut.

Pertama, teknik penelurusan data pada tahapan KPA memuat materi tentang apa saja yang harus dilakukan asesor ketika melakukan penilaian KPA. Materi tersebut juga menyatakan bahwa pentingnya para asesor untuk dapat memahami dengan baik instrumen penilaian prasyarat akreditasi. Para peserta dituntut untuk dapat memastikan bahwa dokumen yang diunggah telah sesuai dengan kondisi satuan PAUD seperti adanya kesinambungan antara satu dokumen dengan dokumen yang lainnya. Untuk lebih jelasnya dapat dilihat pada gambar berikut.

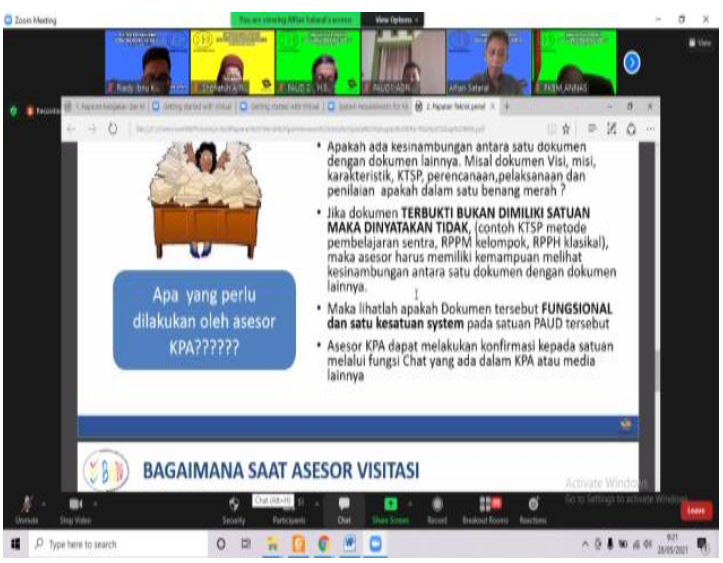

Gambar 1. Materi penelusuran data

Berdasarkan gambar tersebut dapat dilihat bahwa para narasumber menggunakan virtual background pada aplikasi Zoom Meeting yang berwarna biru, panitia menggunakan virtual background berwarna kuning, dan para peserta menggunakan virtual background berwarna hijau.

Kedua, materi Instrumen Penilaian Prasyarat Akreditasi (PPA) PAUD dan PKBM beserta manualnya. Pengabdi sebagai narasumber bersama para peserta membahas setiap butir yang termuat pada masing-masing standar berdasarkan delapan standar nasional pendidikan seperti standar tingkat pencapaian perkembangan, standar isi, standar proses, standar pendidik dan tenaga kependidikan, standar sarana dan prasarana, standar pengelolaan, standar pembiayaan, dan standar penilaian karena berdasarkan instrumen tersebut asesor akan melakukan verivikasi terhadap kesesuaian dokumen satuan PAUD yang diunggah.

Ketiga, para peserta dibagi menjadi dua kelompok untuk mengikuti kegiatan praktik pelaksanaan penilaian akreditasi Klasifikasi Permohonan Akreditasi. Pengabdi sebagai narasumber mendampingi para peserta ketika melakukan praktik penilaian KPA yaitu memberikan penilaian terhadap bukti dokumen satuan PAUD yang telah diupload. Para asesor diharapkan memiliki ketelitian dalam memeriksa keseluruhan dokumen yang diunggah oleh setiap lembaga. Apabila para asesor menemukan adanya ketidaksesuaian bukti dokumen yang diunggah dengan permintaan butir pada setiap indikator, maka asesor yang melakukan penilaian KPA dapat memberikan catatan kepada satuan PAUD agar dapat melakukan perbaikan pada bukti dokumen yang diunggah sehingga dapat memenuhi kesesuaian terhadap permintaan butir.

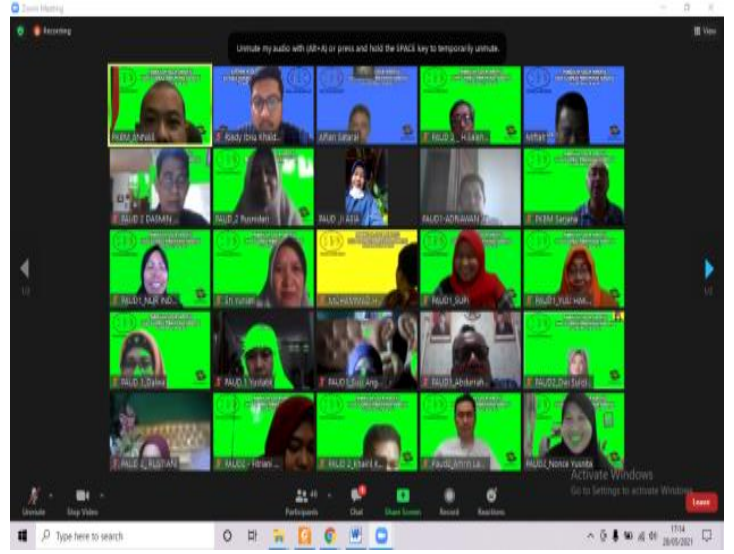

Gambar 2. Pendampingan praktik peserta

Keempat, para peserta diberikan kesempatan untuk memaparkan hasil penilaian KPAnya yang dilanjutkan dengan diskusi secara bersama terkait verivikasi kesesuaian dokumen yang diunggah dan pemberian catatan kepada satuan PAUD yang dinilai melalui menu yang 
tersedia di dalam Sispena 3.1. Diskusi juga dilanjutkan dengan membahas kendala yang dihadapi ketika melakukan penilaian KPA.

Hasil evaluasi kegiatan ini adalah adanya beberapa pertanyaan yang diajukan oleh para peserta pada saat pemberian materi maupun praktik seperti apa saja yang harus dilakukan oleh asesor ketika melakukan penilaian klasifikasi permohonan akreditasi atau KPA, para asesor perlu memperhatikan dengan seksama terkait dengan dokumen yang diunggah oleh satuan PAUD. Selanjutnya, ketika asesor melakukan penilaian klasifikasi permohonan akreditasi dan menemukan adanya bukti dokumen yang diunggah oleh satuan PAUD dianggap belum sesuai dengan yang dipersyaratkan, maka asesor dapat memberikan catatan berupa komentar menggunakan menu yang telah disediakan pada aplikasi Sispena 3.1. Ketersediaan menu memiliki manfaat untuk saling berinteraksi ataupun berkomunikasi di antara asesor yang melakukan penilaian KPA dengan satuan PAUD yang dinilai terkait dengan kesesuaian bukti dokumen yang diunggah disetiap butir dalam masing-masing standar. Untuk lebih jelasnya, dapat dilihat pada gambar berikut ini.

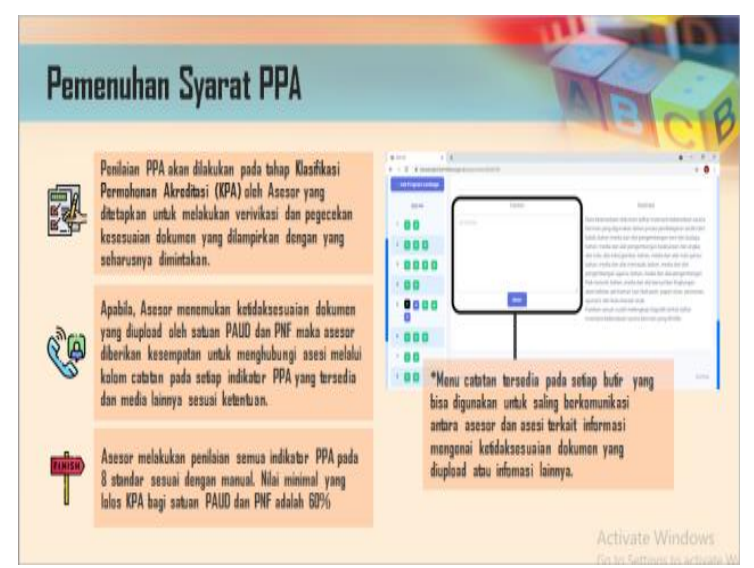

Gambar 3. Menu komentar pada setiap butir

Setiap asesor diwajibkan untuk mengikuti kegiatan pembekalan asesor akreditasi Tahun 2021 baik di tahap klasifikasi permohonan akreditasi, tahap visitasi, maupun di tahap validasi dan verivikasi. Berdasarkan ketentuan yang tertera pada Panduan Pembekalan Asesor Akreditasi Tahun 2021 menyatakan bahwa apabila asesor tidak mengikuti kegiatan pembekalan asesor akreditasi, maka tidak dapat ditugaskan untuk melaksanakan kegiatan akreditasi baik penilaian klasifikasi permohonan akreditasi, visitasi, maupun validasi dan verikasi (BAN PAUD dan PNF, 2021). Pada tahapan akhir kegiatan pembekalan asesor akreditasi tahap KPA, pengabdi selaku narasumber kegiatan melakukan penilaian terhadap para peserta dengan merujuk ke beberapa komponen penilaian yaitu: a) tugas pra-pembekalan asesor akreditasi; b) partisipasi; dan c) praktik penilaian klasifikasi permohonan akreditasi.

\section{SIMPULAN}

Berdasarkan hasil kegiatan dan pembahasan, maka kesimpulan kegiatan pengabdian masyarakat ini adalah kegiatan pembekalan asesor akreditasi tahap KPA Tahun 2021 telah dilaksanakan secara daring dengan tujuan untuk meningkatkan kompetensi asesor dalam melakukan penilaian klasifikasi permohonan akreditasi sesuai dengan panduan pelaksanaan akreditasi Tahun 2021.

\section{UCAPAN TERIMA KASIH}

Pengabdi mengucapkan terima kasih kepada beberapa pihak sebagai berikut: 1) BAN PAUD dan PNF; 2) BAN PAUD dan PNF Provinsi Sulawesi Tengah; 3) Rektor dan Wakil Rektor Universitas Sulawesi Barat; 3) Dekan FISIP Universitas Sulawesi Barat; 4) Ketua LPPM-PM Universitas Sulawesi Barat; dan 5) pihak-pihak lainnya yang tidak dapat disebutkan satu persatu.

\section{DAFTAR RUJUKAN}

BAN PAUD dan PNF. (2021). Panduan Pembekalan Asesor Akreditasi (PAA) Tahun 2021

Farfar, G. (2021). Efektifitas Penggunaan Aplikasi Zoom Meeting Dalam Pembelajaran. ISTORIA: Jurnal Pendidikan Dan Sejarah.

Fikri, A. (2019). Pengaruh Globalisasi dan Era Disrupsi terhadap Pendidikan dan NilaiNilai Keislaman. Sukma: Jurnal Pendidikan. https://doi.org/10.32533/03106.2019

Handayani, R. T., Arradini, D., Darmayanti, A. T., Widiyanto, A., \& Atmojo, J. T. (2020). Pandemi covid-19, respon imun tubuh, dan herd immunity. Jurnal IImiah Stikes Kendal.

Herawati, N., Azis, D., \& Sutrisno, A. (2020). Pengayaan dan Pendampingan Materi Pelajaran Matematika dan Statistika pada Bidang Kesehatan bagi Guru SMKN 2 Tanjung Raya Kabupaten Mesuji Propinsi Lampung. Jurnal Abdidas. https://doi.org/10.31004/abdidas.v115.79

Junining, E., Nuzula, N.F., Purwaningtyas, I., Hartono, D., Setiarini, N., Lailiyah, N. (2021). Upaya Peningkatan Sadar Wisata Berbasis Bahasa dan Kewirausahaan Pada Kegiatan Promosi Kampung Wisata Kungkuk. Selaparang: Jurnal Pengabdian Masyarakat Berkemajuan 
Sari, W., Rifki, A. M., \& Karmila, M. (2020).

Pembelajaran Jarak Jauh Pada Masa

Darurat Covid 19. Jurnal MAPPESONA. 